\title{
Role of cation gradients in hypercontracture of myocytes during simulated ischemia and reperfusion
}

\author{
MASASHI NISHIDA, STEVEN BORZAK, BERNHARD KRAEMER, JORGE P. NAVAS, \\ RALPH A. KELLY, THOMAS W. SMITH, AND JAMES D. MARSH \\ Cardiovascular Division, Brigham and Women's Hospital and Departments of Medicine, Brigham \\ and Women's Hospital and Harvard Medical School, Boston, Massachusetts 02115
}

\begin{abstract}
Nishida, Masashi, Steven Borzak, Bernhard Kraemer, Jorge P. Navas, Ralph A. Kelly, Thomas W. Smith, and James D. Marsh. Role of cation gradients in hypercontracture of myocytes during simulated ischemia and reperfusion. Am. J. Physiol. 264 (Heart Circ. Physiol. 33): H1896-H1906, 1993.-We examined the relationship between transsarcolemmal cation gradients and hypercontracture of cardiac myocytes in ischemia and reperfusion using adult rat ventricular myocytes superfused with buffer mimicking normal or ischemic extracellular fluid. Contractile performance of electrically stimulated cells was recorded by an optical video system simultaneously with measurements of intracellular $\mathrm{Ca}^{2+}$ concentration $\left(\left[\mathrm{Ca}^{2+}\right]_{\mathrm{i}}\right)$ using fura-2 or intracellular $\mathrm{pH}\left(\mathrm{pH}_{\mathrm{i}}\right)$ using $2^{\prime}, 7^{\prime}$-bis(2-carboxyethyl)-5(6)-carboxyfluorescein. While cells were exposed to simulated ischemia buffer, the transsarcolemmal $\mathrm{H}^{+}$gradient was abolished, $\left[\mathrm{Ca}^{2+}\right]_{\mathrm{i}}$ transient stopped, and twitch contraction of myocytes ceased. Upon reperfusion with normal buffer, $\mathrm{H}^{+}$gradient was quickly restored, $\mathrm{Ca}^{2+}$ transients restarted with transient increase in systolic $\mathrm{Ca}^{2+}$, and twitch contraction restarted with development of hypercontracture, which continued after $\left[\mathrm{Ca}^{2+}\right]_{\mathrm{i}}$ returned to preischemic level even in the presence of near-normal concentrations of high-energy phosphates. When the transsarcolemmal proton, $\mathrm{Na}^{+}$, and $\mathrm{Ca}^{2+}$ gradients were altered so that $\mathrm{Na}^{+}$entry via $\mathrm{Na}^{+}-\mathrm{H}^{+}$exchange and $\mathrm{Ca}^{2+}$ entry via $\mathrm{Ca}^{2+}-\mathrm{Na}^{+}$exchange were made less favorable, the transient systolic overshoot of $\mathrm{Ca}^{2+}$ at reperfusion and development of hypercontracture was largely avoided. These results suggest that $\mathrm{Na}^{+}$and then $\mathrm{Ca}^{2+}$ entry via the $\mathrm{Na}^{+}-\mathrm{H}^{+}$and $\mathrm{Na}^{+}-\mathrm{Ca}^{2+}$ exchangers, respectively, probably contribute to the increase in $\left[\mathrm{Ca}^{2+}\right]_{\mathrm{i}}$ and hypercontracture of myocytes at time of reperfusion in this model.
\end{abstract}

fura-2; $2^{\prime}, 7^{\prime}$-bis(2-carboxyethyl)-5(6)-carboxyfluorescein; ischemic injury

ALTHOUGH REPERFUSION of ischemic myocardium is an indispensable therapy of ischemic heart diseases, it is widely acknowledged that reperfusion causes detrimental effects on ischemic heart tissue by itself $(7,30,32)$. In vivo manifestations of "reperfusion injury" are 1) reperfusion arrhythmias, 2) myocardial stunning, and 3) possible exacerbation of necrosis in potentially viable cells in the ischemic region. Despite investigations in diverse model systems from many laboratories, the mechanisms of reperfusion injury remain complex and uncertain (1, 35). This is due in part to the heterogeneous composition of heart tissue. Injury might be caused by direct toxic effects to myocytes of reperfusion or, through vascular injury at reperfusion, manifest as no reflow or extracellular edema (32).

Accumulation of $\mathrm{Ca}^{2+}$ in myocardial tissue is a key element of myocyte injury during reperfusion (35), and there is little doubt that excessive $\mathrm{Ca}^{2+}$ accumulation can be the proximate cause of irreversible cellular injury under some, but not all, ischemia-reperfusion conditions $(38,41)$. However, the interaction between and sequence of events in changes in cytosolic $\mathrm{Ca}^{2+}$ activity, intracellular $\mathrm{Ca}^{2+}$ concentration $\left(\left[\mathrm{Ca}^{2+}\right]_{\mathrm{i}}\right)$, cytosolic $\mathrm{Na}^{+}$activity, intracellular $\mathrm{Na}^{+}$concentration $\left(\left[\mathrm{Na}^{+}\right]_{i}\right)$, or proton activity (intracellular $\mathrm{pH}$, or $\mathrm{pH}_{\mathrm{i}}$ ) or even changes in the absolute concentration of intracellular highenergy phosphates (HEPs) remain incompletely resolved $(34,35)$.

In this study, we used a model of isolated myocytes exposed to simulated ischemic condition. This singlecell model of ischemia, similar to that of Ferrier et al. (14) and Koyama et al. (22), enabled us to evaluate the direct effect of ischemia on cardiac myocytes by excluding diffusion barriers and possible contribution of vascular elements and by avoiding mechanical injury by adjacent cells (17). This model also permits us concurrent assessment of a myocyte's contractile performance and intracellular ion activity using fluorescence dye techniques (5). We specifically sought to determine how changes in the intracellular activities of $\mathrm{Na}^{+}$and $\mathrm{H}^{+}$ could modify $\left[\mathrm{Ca}^{2+}\right]_{\mathrm{i}}$ and contractile function during ischemia and subsequent reperfusion. We tested the hypothesis that the transsarcolemmal $\mathrm{Na}^{+}$gradient plays a pivotal role in initiating a sequence of events that could lead to irreversible cell injury. In a single-cell model, it is also possible to define a unique end point of irreversible reperfusion injury: cell shortening to $60 \%$ of its initial resting length, or "hypercontracture" (17). An experimental model that permits measurement of intracellular ion activities, cellular energetics, and contractile activity is likely to provide results that would allow a more integrated approach to the complex matrix of interacting cellular events during ischemia and reperfusion and may possibly be of greater relevance to events in vivo.

\section{METHODS}

\section{Myocyte Isolation}

Ventricular myocytes were isolated from adult rat hearts by methods described previously (5) with minor modifications. Briefly, female Sprague-Dawley rats (250-300 g, Charles River) were deeply anesthetized with ether. Hearts were removed and were perfused for $25 \mathrm{~min}$ with nominally $\mathrm{Ca}^{2+}$-free KrebsHenseleit bicarbonate (KHB) buffer containing $118 \mathrm{mM} \mathrm{Na}^{+}$, $3.2 \mathrm{mM} \mathrm{K}^{+}$, and $0.05 \%$ collagenase. Ventricles were minced and incubated for $15 \mathrm{~min}$ in KHB buffer with $0.05 \%$ collagenase followed by the addition of 1 vol of KHB buffer with $1.25 \mathrm{mM}$ $\mathrm{Ca}^{2+}$. Dissociation buffers were at $37^{\circ} \mathrm{C}$ and $\mathrm{pH}$ 7.4. Myocytes were released by trituration, filtered through Nytex mesh (100 $\mu \mathrm{m})$, and sedimented through $2 \%$ bovine serum albumin in KHB buffer (1.25 $\left.\mathrm{mM} \mathrm{Ca}^{2+}\right)$. Myocytes were suspended in control buffer (Table 1). All the buffers used for isolation were bubbled with $95 \% \mathrm{O}_{2}-5 \% \mathrm{CO}_{2}$. 
Table 1. Composition of buffers

\begin{tabular}{|c|c|c|c|c|}
\hline & Control & $\begin{array}{l}\text { Ischemia } \\
\text { Buffer }\end{array}$ & $\begin{array}{l}\text { Low } \mathrm{Na}^{+} \\
\text {Buffer }\end{array}$ & $\begin{array}{c}\text { Low } \mathrm{Na}^{+} \\
\text {Ischemia } \\
\text { Buffer }\end{array}$ \\
\hline $\mathrm{NaCl}$ & 130.0 & 110.0 & 60.0 & 40.0 \\
\hline $\mathrm{CaCl}_{2}$ & 1.0 & 1.0 & 1.0 & 1.0 \\
\hline $\mathrm{MgSO}_{4}$ & 1.0 & 1.0 & 1.0 & 1.0 \\
\hline $\mathrm{KCl}$ & 4.0 & 12.0 & 4.0 & 12.0 \\
\hline Glucose & 11.2 & 0.0 & 11.2 & 0.0 \\
\hline HEPES-Na & 10.0 & 10.0 & 10.0 & 10.0 \\
\hline $\mathrm{pH}$ & 7.40 & 6.50 & 7.40 & 6.50 \\
\hline $\begin{array}{l}\text { Osmolality, mosmol/ } \\
\mathrm{kgH}_{2} \mathrm{O}\end{array}$ & 295 & 315 & 290 & 310 \\
\hline Choline chloride & & & 70.0 & 70.0 \\
\hline $\mathrm{NaCN}$ & & 1.5 & & 1.5 \\
\hline 2-Deoxyglucose & & 22.4 & & 22.4 \\
\hline Sodium lactate & & 20.0 & & 20.0 \\
\hline Total $\left[\mathrm{Na}^{+}\right]$ & 140.0 & 141.5 & 70.0 & 71.5 \\
\hline
\end{tabular}

Concentrations are expressed in $\mathrm{mM}$.

\section{Measurements of Contractility and $\left[\mathrm{Ca}^{2+}\right]_{i}$}

Myocyte amplitude of shortening and $\left[\mathrm{Ca}^{2+}\right]_{\mathrm{i}}$ were measured simultaneously by methods we have described previously $(5,6)$ with minor modifications. In brief, myocytes were loaded with fura-2 by incubation of a 2-ml suspension of myocytes $(50,000$ cells $/ \mathrm{ml})$ for $5 \mathrm{~min}$ at $25^{\circ} \mathrm{C}$ with fura-2/AM $(2 \mu \mathrm{M})$ in dimethyl sulfoxide. A glass cover slip with fura-2-loaded myocytes attached was placed in a water-jacketed chamber $\left(37^{\circ} \mathrm{C}\right)$ on the stage of an inverted epifluorescence microscope (Nikon Diaphot). Phase-contrast illumination (700-nm wavelength) was passed through an adjustable aperture, and the image from a single myocyte was directed to a CCD video camera (Pulnix TM $540 / 560$ ) and monitored on a television monitor (Panasonic WV 5470) throughout the experiment. Cell length was measured on the monitor. The image was also directed to a motion detector (Crescent Electronics, Sandy, UT), and amplitude of motion of one end of the cell during tonic or phasic contraction was recorded on a chart recorder (Gould 2200, Cleveland, OH) (6). Cells were also exposed concurrently to illumination from a Spex CM2 dual-excitation spectrofluorimeter (Spex Industries, Edison, NJ) at 340 and $380 \mathrm{~nm}$. Fura-2 emission fluorescence collected from a single myocyte by an adjustable aperture was passed through a band-pass filter $(500 \pm 10 \mathrm{~nm})$ and detected by a photomultiplier tube (Hamamatsu R268UH). Phase-contrast illumination and fura-2 emission fluorescence were separated by a dichroic mirror (600-nm cutoff). Cells were stimulated to contract by a Grass S88 stimulator and a platinum wire field electrode. Stimulation was at $25 \%$ above threshold during the initial control buffers reperfusion, with a 2-ms square-wave pulse. $\left[\mathrm{Ca}^{2+}\right]_{\mathrm{i}}$ was calibrated in situ in each individual myocyte using a procedure previously described and validated in this laboratory (5). Briefly, at the end of the experimental protocol, minimum fura-2 fluorescence was determined by exposing cells to zero $\mathrm{Ca}^{2+}$ buffer containing $1 \mathrm{mM}$ ethylene glycol-bis $(\beta$-aminoethyl ether)- $N, N, N^{\prime}, N^{\prime}$-tetraacetic acid (E('TA), $5 \mathrm{mM}$ pyruvate, and $10 \mu \mathrm{M}$ ionomycin. Maximum fura-2 fluorescence was determined with $1 \mathrm{mM} \mathrm{La}{ }^{3+}$ substituting for EGTA. For control cells, $\mathrm{La}^{3+}$ maintained a relaxed cellular morphology, which is essential for avoiding calibration artifacts. Because fura- 2 has different spectral properties when complexed with $\mathrm{La}^{3+}$ than with $\mathrm{Ca}^{2+}$, scaling factors for $\mathrm{La}^{3+}$ fluorescence were defined in vitro and then verified by experiments in situ. Estimation of $\left[\mathrm{Ca}^{2+}\right]_{\mathrm{i}}$ by the fura-2 method is not importantly perturbed within the $\mathrm{pH}$ range that we utilized $(15,39)$.

Autofluorescence was subtracted before determination of the fluorescence ratio. Autofluorescence was determined in a cellfree area of the cover slip and was subtracted from records at both excitation wavelengths. We have previously established that autofluorescence of cells not loaded with fura-2 does not differ from that of a cell-free area of the cover slip (5). Change in cellular autofluorescence during simulated ischemia is largely due to alterations in pyridine nucleotide autofluorescence, which we have extensively characterized $(13,39)$, and is quantitatively very small compared with the fura-2 fluorescence signal.

Amplitude of cell shortening was taken as an index of contractile state of the cell. Although cells shorten only against the force of the intrinsic viscoelasticity of the cell and that due to cell attachment of the substrate, amplitude of shortening correlates well with actual developed force $(6,40)$.

\section{Measurements of Contractility and Intracellular $\mathrm{H}^{+}$in Myocytes}

Cells were incubated in $N$-2-hydroxyethylpiperazine- $N^{\prime}-2$ ethanesulfonic acid (HEPES)-buffered physiological salt solution containing $2 \mu \mathrm{M} 2^{\prime}, 7^{\prime}$-bis(2-carboxyethyl)-5(6)-carboxyfluorescein (BCECF)/AM at $25^{\circ} \mathrm{C}$ for $30 \mathrm{~min}$ as previously described (5). Cells were then transferred to the stage of the spectrofluorimeter microscope and superfused with control buffer solution at $37^{\circ} \mathrm{C}$. BCECF fluorescence was excited with 450 - and $490-\mathrm{nm}$ light, and fluorescence was detected at $530 \mathrm{~nm}$. Cells were also illuminated with 700-nm light so that amplitude of contraction could be monitored simultaneously. $\mathrm{pH}_{\mathrm{i}}$ was calibrated as follows. At the end of the experiment, cells were superfused with calibration buffer including $10 \mathrm{mM}$ HEPES$\mathrm{KOH}, 0.5 \mathrm{mM}$ EGTA, $5 \mathrm{mM}$ pyruvate, $11 \mathrm{mM}$ glucose, $10 \mathrm{mM}$ $\mathrm{K}$-ATP, $\mathrm{KCl}$ to yield a final $\left[\mathrm{K}^{+}\right]$of $150 \mathrm{mM}, 20 \mu \mathrm{M}$ nigericin, $4 \mu \mathrm{M}$ ionomycin, and $0.2 \mu \mathrm{M}$ carbonyl cyanide $m$-chlorophenylhydrazone (5). Two or three separate calibration buffers were used with the $\mathrm{pH}$ adjusted between 6.40 and 7.30. $\mathrm{pH}_{\mathrm{i}}$ for each cell was then determined by linear interpolation of the plot of fluorescence ratio vs. $\mathrm{pH}$ values of the calibration buffers.

\section{Protocol and Superfusion Buffers}

The basic protocol for simulated ischemia-reperfusion experiments was in accordance with the following sequence: superfusion with the control perfusion buffer for $5 \mathrm{~min}$, followed by superfusion with the simulated ischemia buffer containing cyanide, 2-deoxyglucose, excess $\mathrm{K}^{+}$, and lactate at $\mathrm{pH} 6.50$ (Table 1) for $5 \mathrm{~min}$ and reperfusion with the control buffer for $5 \mathrm{~min}$, or with one of several experimental reperfusion buffers for 4 min, followed by control buffer for $5 \mathrm{~min}$. All experiments (with one exception noted below) followed this protocol. Buffers were equilibrated with room air. To minimize photobleaching and possible toxic effect of ultraviolet light, cells were exposed to periods of continuous excitation light for only 10 -s intervals with $3 \mathrm{~ms} /$ data sampling at 340 - and $380-\mathrm{nm}$ excitation, with 9-ms intervals for acquisition of emission signals at the two excitation wavelengths for ratio spectroscopy. An excitation spectrum of the fura-2 signal between 300 and $400 \mathrm{~nm}$ monitored at $500 \pm 10$-nm emission was performed before and after experiments to assess dye leakage. Experiments in which cell fura-2 fluorescence at $360 \mathrm{~nm}$ (isosbestic point) was reduced by $>50 \%$ at the end of the experiment were rejected from the analysis. To minimize the effect of changes in the intracellular milieu that would influence the fura- 2 emission ratio, cells were calibrated by an in situ calibration technique described above (5). An explicit description of the contents of the normal physiological "control" buffer, the simulated ischemia buffer, and other buffers modified to vary the transsarcolemmal $\mathrm{pH}, \mathrm{Na}^{+}$, and $\mathrm{Ca}^{2+}$ gradients during simulated ischemia and reperfusion is given in Table 1 .

For low $\left[\mathrm{Na}^{+}\right]$perfusion experiments, in which we used low $\left[\mathrm{Na}^{+}\right]$control and ischemia buffer, the $\mathrm{NaCl}$ content of the 
ischemia and reperfusion buffers were reduced to 40 and $60 \mathrm{mM}$, respectively. Choline chloride $(70 \mathrm{mM})$ was added to these buffers to maintain constant ionic strength and osmolarity. For superfusion with $0 \mathrm{mM}\left[\mathrm{Ca}^{2+}\right]$, the ischemia and reperfusion buffer contained $1 \mathrm{mM}$ EGTA instead of $\mathrm{CaCl}_{2}$. All cells attached to cover slips were superfused continuously with buffer at $1 \mathrm{ml} / \mathrm{min}$. The volume of the chamber was $0.8-1.0 \mathrm{ml}$, so that complete superfusate change occurred in $\leq 1 \mathrm{~min}$. Onset of the effect of buffer change occurred typically within 15-30 s. Superfusion of cells with the buffer simulating several elements of ischemia are referred to herein as perfusion with ischemia buffer. Superfusion with control buffer after ischemia buffer will be referred to as reperfusion, by analogy with intact organ ischemia-reperfusion protocols.

\section{HEP Compound Assay}

Cellular content of HEP compounds (creatine phosphate and adenine nucleotides) was determined by high-performance liquid chromatography (HPLC). Freshly isolated myocytes were suspended in control perfusion buffer $(600,000$ cells $/ \mathrm{ml})$. After incubation in experimental buffers in protocols identical to those for contractility experiments, the suspended cells were rapidly centrifuged. HEPs were extracted with $0.3 \mathrm{M}$ perchloric acid and neutralized with $5 \mathrm{M} \mathrm{K}_{2} \mathrm{HPO}_{4}$. After centrifugation, the supernatant was filtered through a $0.45-\mu \mathrm{m}$ filter and HEPs were assayed by HPLC (Waters, Milford, MA). Protein content of cells was assayed by the Lowry method (27). HEP samples were run on an anion-exchange column (Radial-PAK 8PSAX10, Waters) with a mobile phase of $\mathrm{H}_{3} \mathrm{PO}_{4}-\mathrm{KH}_{2} \mathrm{PO}_{4}$ and eluted with a linear gradient. HEPs were detected by an ultraviolet detector at $210 \mathrm{~nm}$ and calibrated by analysis of authentic HEP standards.

\section{Statistics}

Results are expressed as means $\pm \mathrm{SE}$. Means between groups were compared by analysis of variance followed by Scheffé's $F$ test. Distribution between groups was compared by contingency table analysis.

\section{Reagents and Chemicals}

Collagenase (class II) was purchased from Worthington. Fura-2/AM and BCECF were from Molecular Probes (Eugene, OR). Reagents used for HEP determinants were all of HPLC grade and purchased from Fisher (Medford, MA). All other chemicals were reagent grade or better.

\section{RESULTS}

\section{$\left[\mathrm{Ca}^{2+}\right]_{i}$ in Isolated Myocytes}

$\left[\mathrm{Ca}^{2+}\right]_{i}$ and contractility were measured simultaneously in isolated adult myocytes loaded with the fluorescent dye, fura-2, under both control conditions and conditions of simulated ischemia and reperfusion. Figure 1 shows typical $\left[\mathrm{Ca}^{2+}\right]_{\mathrm{i}}$ transients of an isolated adult rat myocyte. Peak systolic and end-diastolic $\left[\mathrm{Ca}^{2+}\right]_{i}$ values from 20 beats during sequential 10-s intervals were averaged for each experiment. Values for isolated adult rat myocytes superfused under control conditions $\left(37^{\circ} \mathrm{C}\right)$ and stimulated at $2.0 \mathrm{~Hz}$ from seven experiments were averaged to give a mean peak systolic $\left[\mathrm{Ca}^{2+}\right]_{\mathrm{i}}$ of $809 \pm 144 \mathrm{nM}$ and end-diastolic $\left[\mathrm{Ca}^{2+}\right]_{i}$ of $72 \pm 6 \mathrm{nM}$.

Although we attempted in situ calibration after the simulated ischemia-reperfusion experiments, unlike control cells these cells did not tolerate the calibration procedure and developed hypercontracture after exposure to ionophores and $\mathrm{La}^{3+}$. We therefore estimated relative

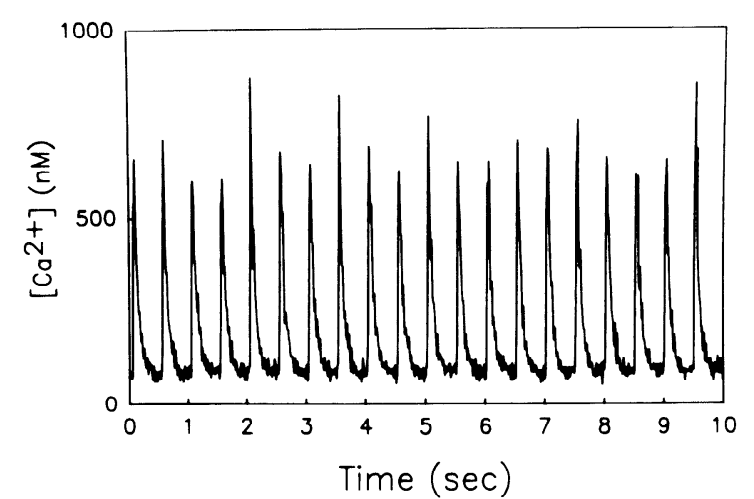

Fig. 1. Intracellular $\mathrm{Ca}^{2+}$ concentration $\left(\left[\mathrm{Ca}^{2+}\right]_{i}\right)$ transients of an isolated rat myocyte. Fluorescence signals from excitation wavelengths 340 and $380 \mathrm{~nm}$ were collected for $3 \mathrm{~ms}$ with $9-\mathrm{ms}$ increments. Background was subtracted, and ratio of fluorescence from 340- and 380-nm excitation was converted to $\left[\mathrm{Ca}^{2+}\right]_{i}$ using in situ calibration. Cell was stimulated at $2 \mathrm{~Hz}$. Unfiltered signal is shown. Experiment was carried out at $37^{\circ} \mathrm{C}$.

changes in $\left[\mathrm{Ca}^{2+}\right]_{\mathrm{i}}$ in these cells by observing changes in the 340 -to-380 $\mathrm{nm}$ ratio, which is related to $\left[\mathrm{Ca}^{2+}\right]_{\mathrm{i}}$ by the equations described by Grynkiewicz et al. (15). Figure 2 illustrates the data gathered from 10 cells subjected to simulated ischemia and reperfusion.

During the control perfusion of the ischemia-reperfusion protocol, both systolic and end-diastolic $\left[\mathrm{Ca}^{2+}\right]_{\mathrm{i}}$ estimated in this manner remained constant. During perfusion with simulated ischemia buffer, the $\left[\mathrm{Ca}^{2+}\right]_{i}$ transient stopped within $2 \mathrm{~min}$ and diastolic $\left[\mathrm{Ca}^{2+}\right]_{\mathrm{i}}$ gradually increased. After reperfusion, $\mathrm{Ca}^{2+}$ transients reappeared within $30 \mathrm{~s}$ and showed a highly reproducible transient overshoot beyond the systolic 340 -to-380 $\mathrm{nm}$ ratio observed during control perfusion. Because calibration could not be performed in these cells, we utilized baseline systolic and diastolic values of 809 and $72 \mathrm{nM}$, respectively, which were determined previously. By application of these terms to the equation of Grynkiewicz et al. (15), the estimated peak $\left[\mathrm{Ca}^{2+}\right]_{i}$ during this overshoot at time of reperfusion was $1,626 \mathrm{nM}$. After this reproducible spike in systolic $\mathrm{Ca}^{2+}$ activity, $\left[\mathrm{Ca}^{2+}\right]_{\mathrm{i}}$ estimated from the

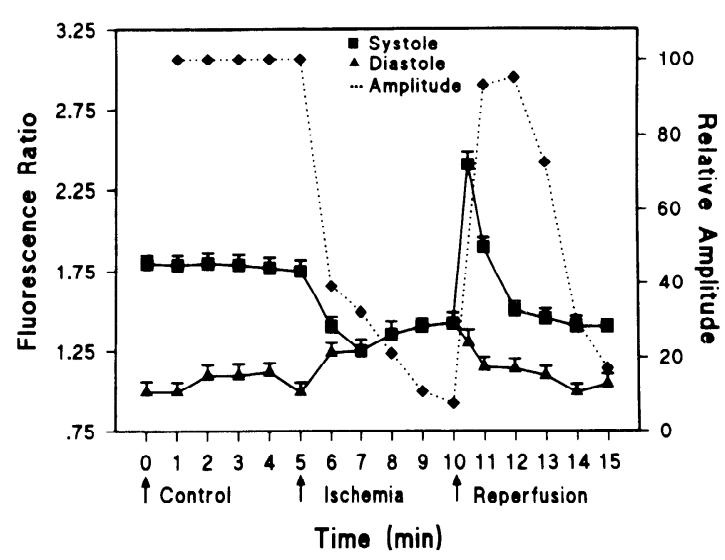

Fig. 2. $\left[\mathrm{Ca}^{2+}\right]_{\mathrm{i}}$ for cells subjected to ischemia and reperfusion. Data were collected intermittently at times indicated during simulated ischemiareperfusion experiments. Data acquisition parameters were 3 -ms integration with $9-\mathrm{ms}$ increment. After subtraction of background, fluorescence from $340 \mathrm{~nm}$ was divided by that from 380-nm excitation. Mean fluorescence ratio is plotted on left ordinate; $n=10$; bars indicate SE. For an additional 6 cells, mean relative amplitude of contraction is plotted. Amplitude during control perfusion is taken as $100 \%$. 
340 -to- $380 \mathrm{~nm}$ ratio returned to control diastolic and less than control systolic levels thereafter. The amplitude of the $\mathrm{Ca}^{2+}$ transient was decreased at this point and corresponded to decreased amplitude of contraction (see below).

\section{Effects of Extracellular Acidosis on $\mathrm{pH}_{i}$ and $\left[\mathrm{Ca}^{2+}\right]_{i}$}

To determine the significance of alterations in cytosolic $\mathrm{pH}$, individual myocytes were exposed to ischemia buffer. This produced a profound decline in cytosolic $\mathrm{pH}$ from a control value of 7.16 to $\mathrm{pH} 6.49$ after $4 \mathrm{~min}$ of exposure (Fig. 3). Upon washout of ischemia buffer the $\mathrm{pH}$ recovered to 7.04 within $4 \mathrm{~min}$, demonstrating that $\left[\mathrm{H}^{+}\right]$gradients could be restored even after this severe degree of intracellular acidosis. This series of experiments was repeated in additional cells in which calibration of the cytosolic $\mathrm{pH}$ in absolute terms was not reliable because of morphological changes during the calibration procedure. Qualitatively similar results were obtained.

To elucidate the effect of changes in cytosolic $\mathrm{pH}$ on $\left[\mathrm{Ca}^{2+}\right]_{\mathrm{i}}$ during reperfusion, we reperfused fura-2-loaded myocytes that had been exposed to simulated ischemia buffer ( $\mathrm{pH}$ 6.50) with reperfusion buffer of $\mathrm{pH} 6.8$ instead of $\mathrm{pH} 7.4$ (Fig. 4). The $\left[\mathrm{Ca}^{2+}\right]_{\mathrm{i}}$ transient was restored within $30 \mathrm{~s}$ after reperfusion with normal physiological buffer at $\mathrm{pH} 6.8$, but the brief overshoot of the $\left[\mathrm{Ca}^{2+}\right]_{\mathrm{i}}$ transient seen with reperfusion with $\mathrm{pH} 7.4$ buffer was consistently not observed. In addition, the amplitude of the $\left[\mathrm{Ca}^{2+}\right]_{\mathrm{i}}$ transient declined to a level below control conditions thereafter and remained depressed. After 5 min of reperfusion at $\mathrm{pH} 6.8$, reperfusion at $\mathrm{pH} 7.4$ was initiated. This produced no further change in the $\left[\mathrm{Ca}^{2+}\right]_{i}$ transient. Therefore, at the time of reperfusion after simulated ischemia, if conditions are such that there is little

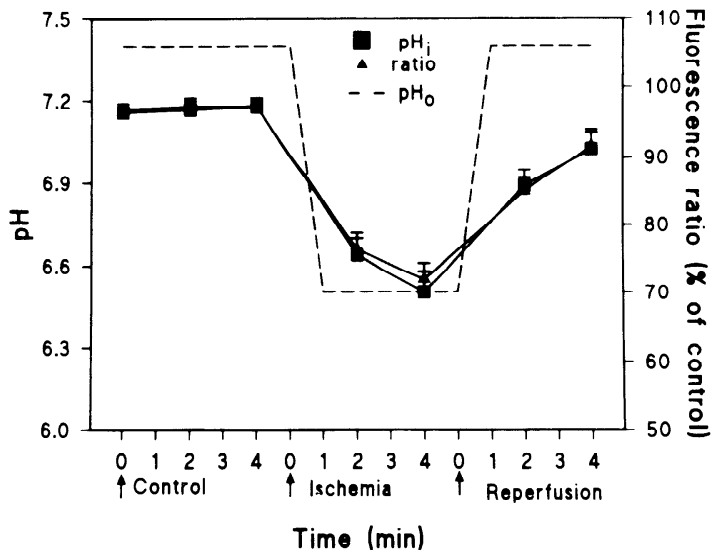

Fig. 3. Cytosolic $\mathrm{pH}\left(\mathrm{pH}_{\mathrm{i}}\right)$ during metabolic inhibition and ischemia. Individual cells were exposed to simulated ischemia buffer $(\mathrm{pH} 6.50) . n$ $=4$. There was a significant $(P<0.05)$ decline in cytosolic $\mathrm{pH}$ during 5 min of simulated ischemia with nearly full recovery upon reperfusion. Control, 5 min of stabilization with control buffer; ischemia, period of simulated ischemia; reperfusion, period of return to superfusion with control buffer. $\mathrm{pH}_{\mathrm{i}}$ is indicated on left ordinate and is determined by $2^{\prime}, 7^{\prime}$-bis (2-carboxyethyl)-5(6)-carboxyfluorescein fluorescence. 'This experiment was repeated for an additional 8 cells whose $\mathrm{pH}$ could not be calibrated in absolute terms. Relative changes in $\mathrm{pH}_{\mathrm{i}}$ were calculated by determining change in fluorescence ratio (right ordinate). Alterations in $\mathrm{pH}_{\mathrm{i}}$ during simulated ischemia were very similar to those for cells in which $\mathrm{pH}$ was calibrated. $\mathrm{pH}_{\mathrm{o}}$, extracellular $\mathrm{pH}$. Cells were exposed to ultraviolet excitation light for only $15-20 \mathrm{~s}$ at each time point to minimize photobleaching.

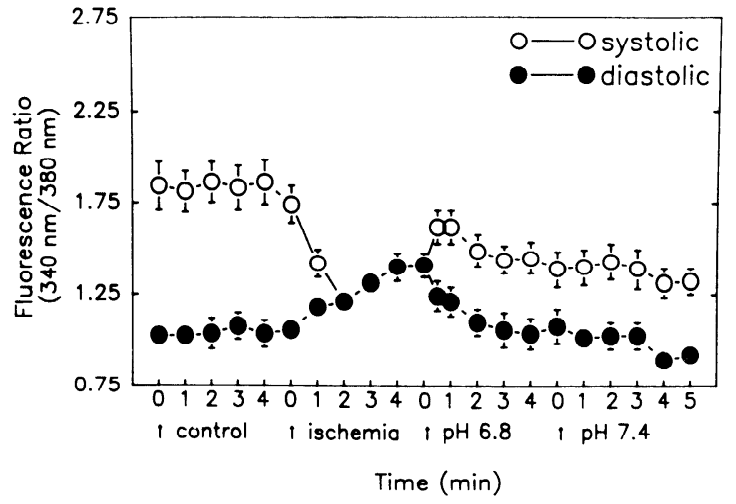

Fig. 4. $\left[\mathrm{Ca}^{2+}\right]_{\mathrm{i}}$ for cells subjected to ischemia and reperfusion at $\mathrm{pH} 6.8$. Cells were superfused with control and ischemia buffer as in Fig. 2 . Reperfusion initially was with control buffer adjusted to $\mathrm{pH} 6.8$ followed by control buffer ( $\mathrm{pH}$ 7.4). Of note, there is no overshoot in $\left[\mathrm{Ca}^{2+}\right]_{\mathrm{i}}$ at time of reperfusion; systolic $\left[\mathrm{Ca}^{2+}\right]_{\mathrm{i}}$ remains below that during control period. $n=11$; bars indicate SE.

if any $\left[\mathrm{H}^{+}\right]_{\mathrm{i}}$ gradient across the sarcolemma, the reperfusion-related brief increase in systolic $\left[\mathrm{Ca}^{2+}\right]_{\mathrm{i}}$ was abolished and $\left[\mathrm{Ca}^{2+}\right]_{\mathrm{i}}$ remained consistently depressed.

\section{Effect of Extracellular $\mathrm{Ca}^{2+}$ and $\mathrm{Na}^{+}$}

\section{on $\left[\mathrm{Ca}^{2+}\right]_{i}$ Transient}

In addition to changes in the transsarcolemmal $\mathrm{H}^{+}$ gradient, the $\mathrm{Na}^{+}$gradient across the sarcolemma would also probably affect $\left[\mathrm{Ca}^{2+}\right]_{i}$. We therefore examined the effect of low $\mathrm{Na}^{+}$buffers (see Table 1) during the ischemic and reperfusion portions of the protocol. As illustrated in Fig. 5, perfusion with control buffer was followed by perfusion with the standard ischemia buffer $(\mathrm{pH}$ 6.50 ) for $5 \mathrm{~min}$ followed by a 5 -min perfusion with a low $\mathrm{Na}^{+}$ischemia buffer ( $\mathrm{pH}$ 6.50) and finally, reperfusion for 5 min with low $\mathrm{Na}^{+}$reperfusion buffer $(\mathrm{pH} 7.4)$. Thus, unlike other experiments, in this experiment cells were in ischemia buffer for $10 \mathrm{~min}$. In fura-2-loaded myocytes exposed to this sequence of buffers, the $\left[\mathrm{Ca}^{2+}\right]_{\mathrm{i}}$ transient ceased during perfusion with ischemia buffer. The mean $\left[\mathrm{Ca}^{2+}\right]_{\mathrm{i}}$ as estimated by the 340 -to-380 $\mathrm{nm}$ fluorescence ratio tended to increase gradually during perfusion with low extracellular $\left[\mathrm{Na}^{+}\right]$ischemia buffer. After perfusion

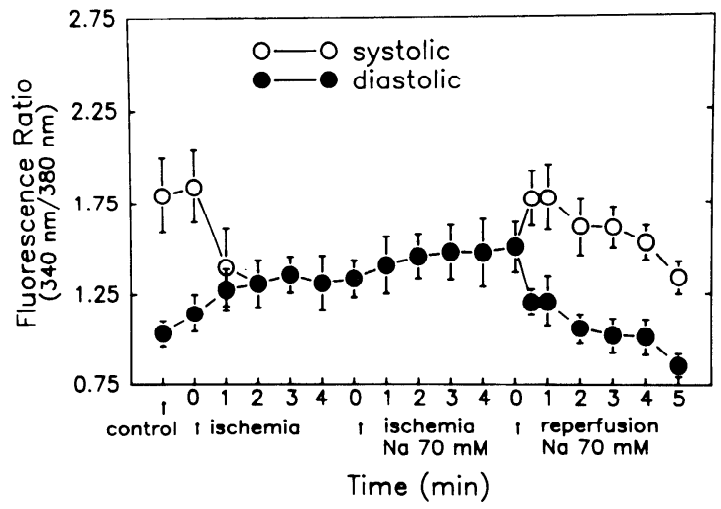

Fig. $\left.5 . \mathrm{Ca}^{2+}\right]_{\mathrm{i}}$ for cells subjected to ischemia and reperfusion with low $\left[\mathrm{Na}^{+}\right]$buffer. Cells were stabilized initially for $10 \mathrm{~min}$ in control buffer. Protocol as in Fig. 2, except that after $5 \mathrm{~min}$ of ischemia cells were superfused for an additional $5 \mathrm{~min}$ with ischemia buffer containing 71 $\mathrm{mM} \mathrm{Na}$ and then with control buffer (reperfusion) containing $70 \mathrm{mM}$ $\mathrm{Na}$. Of note, during reperfusion cytosolic $\left[\mathrm{Ca}^{2+}\right]_{i}$ did not exceed control values. $n=4$; bars indicate $S E$. 
with low $\mathrm{Na}^{+}$reperfusion buffer, $\left[\mathrm{Ca}^{2+}\right]_{\mathrm{i}}$ transients recovered after $30 \mathrm{~s}$. As was the case with reperfusion with control buffer at $\mathrm{pH} 6.8$ shown in Fig. 4, the overshoot of the $\left[\mathrm{Ca}^{2+}\right]_{\mathrm{i}}$ transient was not observed, in marked contrast to the overshoot seen with reperfusion with physiological buffers at $\mathrm{pH}$ 7.4. The amplitude of the $\left[\mathrm{Ca}^{2+}\right]_{i}$ transient also decreased to a level below control conditions after $4 \mathrm{~min}$ of reperfusion. If cells were exposed to ischemia buffer for $5 \mathrm{~min}$ and then directly switched to 70 $\mathrm{mM} \mathrm{Na}{ }^{+}$reperfusion buffer, they immediately developed hypercontracture (data not shown).

To determine the contribution of extracellular $\mathrm{Ca}^{2+}$ to the observed changes in $\left[\mathrm{Ca}^{2+}\right]_{\mathrm{i}}$ during ischemia and reperfusion we also examined the effect of very low $\mathrm{Ca}^{2+}$ buffers. Fura-2-loaded myocytes were perfused initially with the physiological control buffer as in the protocols described above, exposed to $0 \mathrm{mM}\left[\mathrm{Ca}^{2+}\right]$ (1 mM EGTA) ischemia buffer for $5 \mathrm{~min}$ instead of the regular ischemia buffer and then reperfused with a $0 \mathrm{mM}\left[\mathrm{Ca}^{2+}\right]$ control buffer ( $\mathrm{pH}$ 7.4) followed by reperfusion with regular control buffer $\left(1 \mathrm{mM} \mathrm{Ca}^{2+}\right)$. Figure 6 illustrates the changes in the 340 -to-380 $\mathrm{nm}$ fluorescence ratio during those experiments. $\left[\mathrm{Ca}^{2+}\right]_{\mathrm{i}}$ transients ceased after perfusion with zero $\mathrm{Ca}^{2+}$ ischemia buffer, and the mean fluorescence ratio under these conditions was significantly lower than that observed during perfusion with $1 \mathrm{mM} \mathrm{Ca}^{2+}$ ischemia buffer. $\left[\mathrm{Ca}^{2+}\right]_{\mathrm{i}}$ transients did not reappear upon reperfusion with zero $\mathrm{Ca}^{2+}$ control buffer at $\mathrm{pH} 7.4$, but they did reappear upon perfusion with the regular control buffer (1 $\mathrm{mM} \mathrm{Ca}{ }^{2+}$ ) within $2 \mathrm{~min}$. There was no initial overshoot or sustained augmentation of either the amplitude or systolic and diastolic values of subsequent $\mathrm{Ca}^{2+}$ transients.

\section{Contractile Function of Isolated Ventricular Myocytes During Ischemia and Reperfusion}

In each of the protocols described above, contractile amplitude was recorded continuously and simultaneously while fura-2 or BCECF fluorescence signals were acquired. Figure $7 \mathrm{~A}$ shows a typical recording of myocyte contractile amplitude in a myocyte stimulated at $2.0 \mathrm{~Hz}$ and perfused initially with physiological control buffer and then exposed to simulated ischemia buffer followed by reperfusion with a standard control buffer. Immedi-

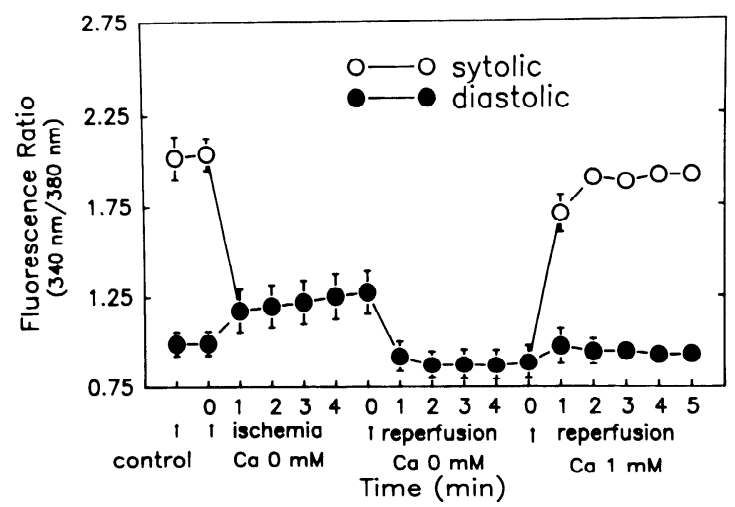

Fig. 6. $\left[\mathrm{Ca}^{2+}\right]_{\mathrm{i}}$ for cells subjected to ischemia and reperfusion with low $\left[\mathrm{Ca}^{2+}\right]_{\mathrm{i}}$ buffer. Protocol as in Fig. 2, except that during ischemia and initial $5 \mathrm{~min}$ of reperfusion, extracellular $\left[\mathrm{Ca}^{2+}\right]$ was nominally 0 . Of note, during reperfusion with $1 \mathrm{mM} \mathrm{Ca}{ }^{2+}$ control buffer, systolic $\left[\mathrm{Ca}^{2+}\right]_{\mathrm{i}}$ did not exceed control value. $n=5$; bars indicate $\mathrm{SE}$. ately after perfusion with the ischemia buffer ( $\mathrm{pH} 6.50)$, there was transient augmentation of contractile amplitude followed by cessation of contraction within 2 min. The length of the quiescent cell increased slightly during perfusion with ischemia buffer. After reperfusion with control perfusion buffer, cell contraction was restored within $30 \mathrm{~s}$, concurrent with the restoration of $\left[\mathrm{Ca}^{2+}\right]_{\mathrm{i}}$ transients. The amplitude of contraction was typically two to three times greater than amplitude of contraction during the initial preischemic control buffer perfusion. Amplitude of contraction subsequently declined to less than control amplitude. Hypercontracture developed during the time that amplitude was declining, with shortening of the diastolic length of the cell until the cell reached a square form. This excessive shortening of the diastolic length of the cell, or hypercontracture, was observed in $85 \%$ of cells after metabolic inhibition with ischemia buffer followed by reperfusion with control buffer (Table 2) and occurred regardless of whether cells were loaded with fura-2 or BCECF or were exposed to periodic ultraviolet excitation light.

The contractile performance of cells in bicarbonatecontaining buffer was also examined. The composition of the bicarbonate buffers was identical to that for the preceding experiments except that HEPES was deleted, 18 $\mathrm{mM} \mathrm{NaHCO}{ }_{3}$ was added, and buffers were equilibrated with $5 \% \mathrm{CO}_{2}$. The $\mathrm{pH}$ of the buffer determined by a $\mathrm{pH}$ indicator did not change significantly during its passage through the chamber. After $5 \mathrm{~min}$ of simulated ischemia, all cells in $\mathrm{NaHCO}_{3}$ buffer developed hypercontracture when subjected to reperfusion at $\mathrm{pH} 7.4$ (Table 2), similar to the pattern for cells in HEPES buffer.

To examine the effect of a low $\mathrm{pH}$ reperfusion buffer on contractility and diastolic cell shortening, myocytes superfused with ischemia buffer for 5 min were then reperfused with control buffer at $\mathrm{pH} 6.8$ instead of $\mathrm{pH} 7.4$ (Fig. $7 B$ ). As observed previously, contraction stopped during perfusion with simulated ischemia buffer but recovered rapidly after reperfusion with buffer at $\mathrm{pH} \mathrm{6.8.} \mathrm{The}$ twitch amplitude increased gradually to $75 \%$ of that seen with control buffer perfusion within 2 min and remained at this slightly diminished level thereafter. The transient augmentation in twitch amplitude followed by hypercontracture observed with reperfusion at $\mathrm{pH} 7.4$ was not observed with reperfusion at $\mathrm{pH}$ 6.8. If myocytes were exposed to normal physiological buffer at $\mathrm{pH} 7.4$ after initial reperfusion with physiological buffer at $\mathrm{pH} 6.8$ for $5 \mathrm{~min}$, it was uncommon for these cells to develop hypercontracture.

\section{Ischemia, Reperfusion, and Myocyte Hypercontracture}

Excessive diastolic shortening of myocytes to $<60 \%$ of the cell's original length during diastole (hypercontracture) was used as an indicator of irreversible cell injury. In no case did we observe a cell that had undergone diastolic shortening of $\geq 60 \%$ during reperfusion subsequently lengthen (relax) despite observing over 200 cells for at least $45 \mathrm{~min}$. Cells exposed to ischemia buffer for $5 \mathrm{~min}$ and then control buffer for 5 min were observed for uptake of trypan blue. Of cells that developed contracture to $<60 \%$ of initial length $75 \pm 3.9 \%$ no longer excluded 
A

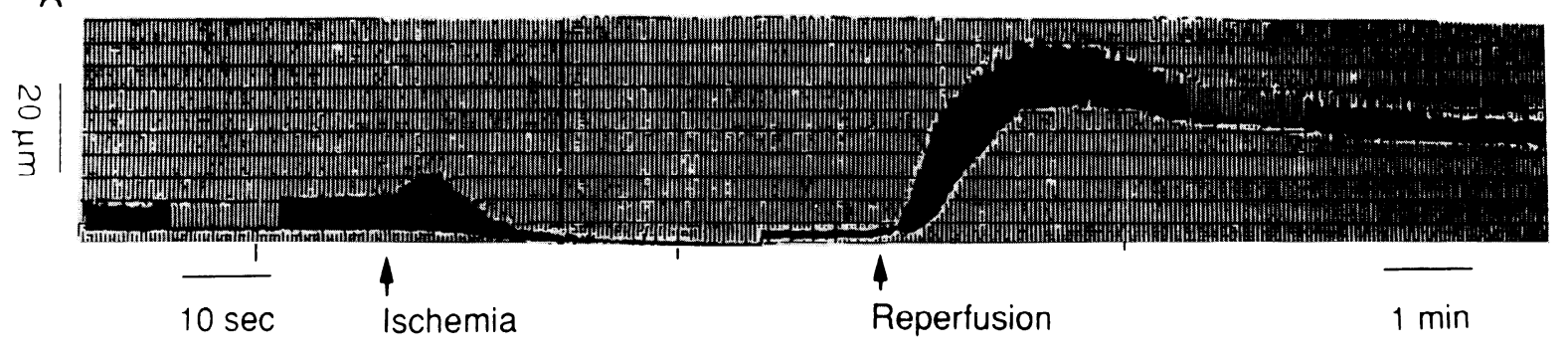

$\mathrm{pH} 7.4$

B

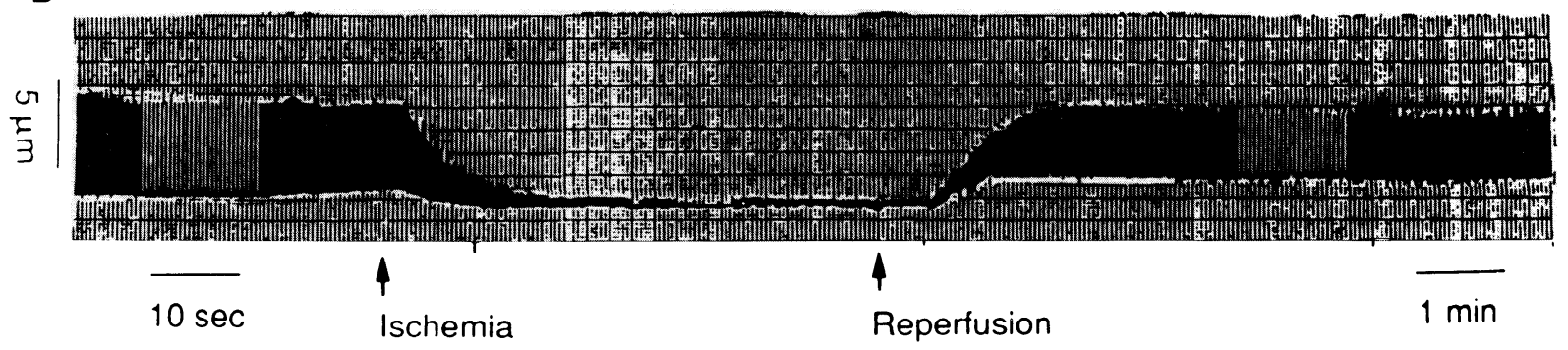

$\mathrm{pH} 6.8$

Fig. 7. Contraction of an isolated adult rat myocyte during simulated ischemia-reperfusion. Upward movement of recording shows contraction of a myocyte. Amplitude of contraction is shown on ordinate. Scale of abscissa is expanded at 2 portions of recording to show each contraction. Time resolution of recording was $16.7 \mathrm{~ms}$. $A$ : reperfusion with control buffer ( $\mathrm{pH}$ 7.4). Note prominent diastolic shortening. $B$ : reperfusion with $\mathrm{pH} 6.8$ control buffer. Note that diastolic shortening is markedly attenuated with $\mathrm{pH} 6.8$ reperfusion buffer.

trypan blue, indicating significant sarcolemmal damage $(n=7$ expt; $60-200$ cells counted/expt); $100 \%$ of rodshaped cells in control buffer excluded trypan blue.

The incidence of hypercontracture after simulated ischemia and reperfusion is summarized in Table 2. Myocytes studied under a variety of ischemia-reperfusion protocols were divided into three groups based on the ratio of preischemic cell length to postreperfusion length. The "normal" group comprised cells maintaining $>90 \%$ of their preischemic diastolic cell length (reversible injury). The "moderate contracture" group contained cells whose diastolic cell length was $>60 \%$ and $<90 \%$ of control cell length. Based on the absence of any example of a return to a preischemic diastolic cell length, we judge these moderately contracted cells to probably be irreversibly injured. Cells shortened to $<60 \%$ of initial length were

Table 2. Percentage of myocytes developing hypercontracture after stimulated ischemia-reperfusion

\begin{tabular}{lrccc}
\hline \hline \multicolumn{1}{c}{$\begin{array}{c}\text { Reperfusion } \\
\text { Protocol }\end{array}$} & $n$ & Normal & $\begin{array}{c}\text { Moderate } \\
\text { Contracture }\end{array}$ & Hypercontracture \\
\hline pH 7.4 & 28 & 10.7 & 3.6 & 85.7 \\
pH 7.4 & 6 & 0 & 0 & 100 \\
$\quad$ (bicarbonate buffer) & & & & \\
pH 6.8 & 21 & 90.5 & 0.0 & $9.5^{*}$ \\
{$\left[\mathrm{Na}^{+}\right]_{0}(70 \mathrm{mM})$} & 21 & 81.0 & 0.0 & $19.0^{*}$ \\
Tetrodotoxin & 9 & 100 & 0 & $0^{*}$ \\
Amiloride $(100 \mu \mathrm{M})$ & 9 & 100.0 & 0.0 & $0.0^{*}$ \\
{$\left[\mathrm{Ca}^{2+}\right]_{0}(0 \mathrm{mM})$} & 15 & 86.7 & 6.7 & $6.7^{*}$ \\
\hline
\end{tabular}

$n$, No. of cells studied; normal, cell length $\geq 90 \%$ of original; moderate contracture, $90 \%>$ cell length $\geq 60 \%$ of original; hypercontracture, cell length $<60 \%$ of original. Tetrodotoxin $(15 \mu \mathrm{M})$ was present in ischemia buffer but not in reperfusion buffer. ${ }^{*} P<0.0005$ vs. $\mathrm{pH} 7.4$ reperfusion protocol using contingency table analysis. termed hypercontracted. Therefore, using diastolic shortening to $<60 \%$ of control length as an index of irreversible injury, we studied the effect of varying the transsarcolemmal $\mathrm{pH}, \mathrm{Ca}^{2+}$, and $\mathrm{Na}^{+}$gradients during simulated reperfusion on myocyte contractile function and the development of hypercontracture.

Reperfusion at $p H$ 6.8. Eighty-six percent of myocytes perfused with simulated ischemia buffer for $5 \mathrm{~min}$ followed by reperfusion with normal control buffer at physiological pH (7.4) developed hypercontracture (Table 2). In marked contrast, if cells exposed to simulated ischemia buffer were reperfused initially with low $\mathrm{pH}$ control buffer ( $\mathrm{pH}$ 6.8) for 5 min followed by perfusion with $\mathrm{pH}$ 7.4 buffer for $5 \mathrm{~min}$, only $9.5 \%$ of cells developed hypercontracture.

Reperfusion with low $\mathrm{Na}^{+}$(70 $\mathrm{mM}$ ) buffer or amiloride. To evaluate the effect of varying the sarcolemmal $\mathrm{Na}^{+}$ gradient on myocyte contracture, we reperfused myocytes with low $\mathrm{Na}^{+}$buffer $\left(\left[\mathrm{Na}^{+}\right]=70 \mathrm{mM}\right)$. When the cells were reperfused with low $\left[\mathrm{Na}^{+}\right]$buffer directly after simulated ischemia buffer $\left(140 \mathrm{mM} \mathrm{Na}{ }^{+}\right)$, cells developed blebs and changed into hypercontracted round forms. This may have occurred because, upon change in perfusate composition at time of reperfusion, it would take several seconds to lower the effective $\left[\mathrm{Na}^{+}\right]$at the external sarcolemmal surface. Cells were therefore reperfused with a low $\left[\mathrm{Na}^{+}\right](70 \mathrm{mM})$ ischemia buffer for 5 min after regular ischemia buffer and reperfused with a low $\left[\mathrm{Na}^{+}\right]$ (70 $\mathrm{mM}$ ) control buffer followed by control buffer ([ $\left.\mathrm{Na}^{+}\right]$ $=140 \mathrm{mM}$ ). This protocol produced a $19 \%$ incidence of hypercontracture (Table 2). To determine whether blockade of sarcolemmal $\mathrm{Na}^{+}-\mathrm{H}^{+}$exchanger would prevent the marked degree of cell shortening observed with $140 \mathrm{mM}$ 
$\mathrm{Na}^{+}$control buffer, myocytes were exposed to $100 \mu \mathrm{M}$ amiloride immediately before and during simulated reperfusion. Amiloride effectively prevented any hypercontracture of cells reperfused with $140 \mathrm{mM} \mathrm{Na}^{+}$and demonstrated no consistent positive or negative inotropic effect in this protocol. Thus hypercontracture of myocytes was prevented by $100 \mu \mathrm{M}$ amiloride-containing buffers as well as low $\left[\mathrm{Na}^{+}\right]$buffer (Table 2).

$\mathrm{Na}^{+}$channel blockade. $\mathrm{Na}^{+}$entry via the $\mathrm{Na}^{+}$channel during simulated ischemia may contribute to $\mathrm{Na}^{+}$overload if the action potential persists or if $\mathrm{Na}^{+}$channels remain in an open state. To test this hypothesis, ischemia buffer was supplemented with $15 \mu \mathrm{M}$ tetrodotoxin (TTX). When cells were superfused with control buffer after 5 min ischemia and TTX, no cells developed hypercontracture, and all cells began contracting again but with diminished amplitude (Table 2).

Reperfusion with low $\mathrm{Ca}^{2+}$ buffer. The effect of zero $\mathrm{Ca}^{2+}$ reperfusion on cell shortening and contractile function was also examined. Reperfusion with $0 \mathrm{mM}\left[\mathrm{Ca}^{2+}\right]-1$ mM EGTA control buffer directly after simulated ischemia induced bleb formation and rapid rounding up of myocytes. As is the case with low extracellular $\mathrm{Na}^{+}$reperfusion, cells were perfused with modified ischemia buffer containing $0 \mathrm{mM}\left[\mathrm{Ca}^{2+}\right]-1 \mathrm{mM}$ EGTA ischemia buffer after $5 \mathrm{~min}$ of metabolic inhibition with the usual $1 \mathrm{mM} \mathrm{Ca}^{2+}$ ischemia buffer and then reperfused with 0 $\mathrm{mM}\left[\mathrm{Ca}^{2+}\right]-1 \mathrm{mM}$ EGTA control buffer followed by regular control buffer. This zero $\mathrm{Ca}^{2+}$ ischemia-reperfusion protocol abolished $\left[\mathrm{Ca}^{2+}\right]_{\mathrm{i}}$ overshoot and significantly reduced, but did not abolish, hypercontracture of myocytes, as indicated in Table 2.

Hypercontracture and duration of ischemic injury. The effect of duration of ischemic perfusion on myocyte viability as determined by the development of hypercontracture was also examined (Table 3). Cells were superfused for graded periods with simulated ischemia buffer. When myocytes were reperfused with control buffer at $\mathrm{pH}$ 7.4, most of the cells developed hypercontracture at any duration of ischemic perfusion lasting $\geq 5 \mathrm{~min}$. Reperfusion with buffer at $\mathrm{pH} 6.8$ prevented the cells from developing hypercontracture in every experiment from 5 to $20 \mathrm{~min}$ of ischemia.

Table 3. Duration of ischemia and percentage of myocytes developing hypercontracture

\begin{tabular}{|c|c|c|c|c|c|c|c|c|}
\hline \multirow{2}{*}{$\begin{array}{c}\text { Ischemia } \\
\text { Duration, } \\
\text { min }\end{array}$} & \multicolumn{4}{|c|}{$\mathrm{pH} 7.4$} & \multicolumn{4}{|c|}{$\mathrm{pH} 6.8$} \\
\hline & $n$ & $I$ & $I I$ & $I I I$ & $n$ & $I$ & $I I$ & III \\
\hline 0 & 10 & 100 & 0 & $0^{*}$ & & & & \\
\hline 5 & 10 & 10 & 10 & $80^{*}$ & 5 & 100 & 0 & 0 \\
\hline 10 & 9 & 11 & 11 & $78^{*}$ & 5 & 100 & 0 & 0 \\
\hline 15 & 10 & 20 & 30 & $50^{*}$ & 5 & 100 & 0 & 0 \\
\hline 20 & 6 & 0 & 33 & $67^{*}$ & 6 & 100 & 0 & 0 \\
\hline
\end{tabular}

Protocol: for $\mathrm{pH} 7.4$ reperfusion cells were stabilized in control buffer for $5 \mathrm{~min}$, exposed to ischemia buffer for indicated period of time, and then reperfused with control buffer $(\mathrm{pH}$ 7.4) for $10 \mathrm{~min}$. For $\mathrm{pH} 6.8$ reperfusion, protocol as above except that initial reperfusion was with pH 6.80 buffer for $10 \mathrm{~min}$ and then pH 7.40 buffer for $10 \mathrm{~min}$. $n$, No. of cells studied; $I$, cell length $\geq 90 \%$ of original (normal); $I I, 90 \%>$ cell length $\geq 60 \%$ of original (moderate contracture); $I I I$, cell length $<60 \%$ of original (hypercontracture). ${ }^{*} P<0.002$ vs. ischemia duration 0 min using contingency table analysis.

\section{Effect of $\mathrm{K}^{+}$and Lactate}

To determine the effect of elevation in superfusate $\left[\mathrm{K}^{+}\right]$alone on cell contractile properties, cells were superfused with control buffer for 5 min, with buffer containing $12 \mathrm{mM} \mathrm{KCl}$ for $10 \mathrm{~min}$ and then with control buffer for $5 \mathrm{~min}$. Amplitude of contraction declined for all cells during $12 \mathrm{mM} \mathrm{KCl}$ superfusion $(n=5)$, and two cells ceased contracting. During reperfusion with control buffer, amplitude of contraction was, on average, moderately depressed. Resting cell length was entirely unchanged comparing length in control buffer, $12 \mathrm{mM} \mathrm{KCl}$, and at end of reperfusion.

The effect of an additional component of ischemia buffer, $20 \mathrm{mM}$ lactate ( $\mathrm{pH} 7.4)$, was studied in isolation using an identical protocol. Lactate only produced a decline in amplitude of contraction to $28 \pm 5 \%$ of control. With washout, amplitude recovered to $80 \pm 8 \%$ of control by $5 \mathrm{~min}$. There was no change in resting cell length during or after lactate superfusion.

\section{HEP Compounds and Simulated Ischemic Perfusion in Isolated Myocytes}

HEP compound content of myocytes is an important determinant of contractile state and probably of cell viability. We measured HEP content in isolated adult rat myocytes by HPLC (Table 4). In control myocytes, superfused with physiological buffer at $\mathrm{pH} 7.4$, the ATP and $\mathrm{ADP}$ contents were $22.6 \pm 1.7$ and $3.6 \pm 0.3 \mathrm{nmol} / \mathrm{mg}$ protein, respectively, and the ATP-to-ADP ratio was $6.5 \pm 0.4$. Creatine phosphate content was $29.6 \pm 1.0$ $\mathrm{nmol} / \mathrm{mg}$ protein. When myocytes were exposed to control buffer perfusion followed by simulated ischemia buffer for 5 min, the content of ATP and ADP did not decrease significantly but did decrease significantly if the duration of simulated ischemia was lengthened to $10 \mathrm{~min}$. The ratio of ATP to ADP and [creatine phosphate] were significantly decreased by $5 \mathrm{~min}$, however. After resuspension in pH 7.4 control buffer after $5 \mathrm{~min}$ of ischemia buffer, the ATP and ADP contents did not change and the ATP-to-ADP ratio and the creatine phosphate content returned toward normal. One important difference between myocytes being examined on a cover slip for $\left[\mathrm{Ca}^{2+}\right]_{\mathrm{i}}$ or $\mathrm{pH}_{\mathrm{i}}$ and contractility measurements and myocytes in suspension used for determination of HEP content is that myocytes on a cover slip stimulated at $2 \mathrm{~Hz}$ typically contract for the initial 1-2 $\mathrm{min}$ in ischemia buffer before becoming quiescent for the subsequent 3-4

\section{Table 4. Concentration of high-energy phosphate compounds in adult rat myocytes during simulated ischemia-reperfusion}

\begin{tabular}{lcclc}
\hline \hline & ATP & ADP & ATP/ADP & CrP \\
\hline Control & $22.6 \pm 1.7$ & $3.6 \pm 0.3$ & $6.5 \pm 0.4$ & $29.6 \pm 1.0$ \\
Ischemia (5 min) & $19.7 \pm 1.1$ & $4.3 \pm 0.2$ & $4.5 \pm 0.2^{*}$ & $20.5 \pm 1.1^{*}$ \\
Reperfusion $\dagger(5 \mathrm{~min})$ & $20.0 \pm 1.0$ & $3.6 \pm 0.2$ & $5.7 \pm 0.5$ & $23.6 \pm 1.1^{*}$ \\
Ischemia $\neq(10 \mathrm{~min})$ & $8.1 \pm 0.4^{*}$ & $7.0 \pm 0.4^{*}$ & $1.2 \pm 0.1^{*}$ & $5.4 \pm 0.3^{*}$ \\
\hline
\end{tabular}

Values are means $\pm \mathrm{SE}$ given in $\mathrm{nmol} / \mathrm{mg}$ protein; $n=6 \mathrm{CrP}$, creatine phosphate. ${ }^{*} P<0.05$ vs. control using Scheffé's $F$ test after analysis of variance. + Cells subjected to ischemia buffer for 5 min and then control buffer for $5 \mathrm{~min}$. $\ddagger$ Cells subjected to ischemia buffer for 10 min; no reperfusion. 
min, whereas myocytes in suspension are not stimulated and are presumed to be relatively quiescent throughout the protocol. Thus the data from cells exposed to the simulated ischemia protocol at 5 min probably overestimates HEPs compared with stimulated cells on a cover slip at $5 \mathrm{~min}$. HEPs at $10 \mathrm{~min}$ are likely to be underestimated but serve to bracket the value for cells on a cover slip. The absolute values of HEPs and the ATP-to-ADP ratio in control cells demonstrates that these myocytes have good energy stores initially and from this perspective serve as an adequate model for studies of ischemia and reperfusion.

\section{DISCUSSION}

These studies help to define the interrelationship among irreversible myocyte injury at reperfusion and several important determinants of cell function and viability, including the transsarcolemmal $\mathrm{Ca}^{2+}, \mathrm{H}^{+}$, and $\mathrm{Na}^{+}$gradients and cellular HEP content. There are four major observations in this report.

The first observation is the triphasic change in $\left[\mathrm{Ca}^{2+}\right]_{i}$ during simulated ischemia followed by reperfusion. Under our experimental conditions, the diastolic $\left[\mathrm{Ca}^{2+}\right]_{\mathrm{i}}$ is 72 $\mathrm{nM}$ and peak systolic $\left[\mathrm{Ca}^{2+}\right]_{\mathrm{i}}$ is $809 \mathrm{nM}$ for a normally contracting adult rat myocyte at $37^{\circ} \mathrm{C}$ stimulated at $2 \mathrm{~Hz}$. During simulated ischemia, the $\mathrm{Ca}^{2+}$ fluorescence ratio of the quiescent cell is maintained at a value between values of diastolic and systolic found under control conditions. Thus, during $5 \mathrm{~min}$ of simulated ischemia with $1 \mathrm{mM}$ extracellular $\left[\mathrm{Ca}^{2+}\right]$, there is no major increase in cytosolic $\mathrm{Ca}^{2+}$ concentration. Interestingly, upon reperfusion, when the ischemia buffer is washed out with control buffer, there is an immediate and transient increase in systolic $\mathrm{Ca}^{2+}$ to $\sim 200 \%$ of the control value, which was followed by returning to normal or moderately declining levels of diastolic and systolic $\mathrm{Ca}^{2+}$.

The second finding is the dissociation of contractile amplitude from $\left[\mathrm{Ca}^{2+}\right]_{\mathrm{i}}$ upon reperfusion after simulated ischemia. Cell contractility, which stops during simulated ischemia for $5 \mathrm{~min}$, resumes at reperfusion with a transient augmentation in the amplitude that is associated with a transient increase in systolic $\mathrm{Ca}^{2+}$. We consistently observed the subsequent development of contracture (failure of diastolic relaxation) that occurred despite the presence of normal or moderately declining levels of diastolic and systolic $\mathrm{Ca}^{2+}$. Importantly, contracture developed at a time when neither the concentration of ATP nor the ATP-to-ADP ratio were significantly depressed and the concentration of creatine phosphate was only modestly decreased, at least when studied in quiescent myocytes in suspension exposed to identical buffers for the same duration of time. Thus contracture of a myocyte can occur in the presence of normal or near-normal HEP concentrations and in the presence of a cytosolic $\mathrm{Ca}^{2+}$ activity that has returned to normal after a transient, but probably important, elevation.

A third observation is that, during simulated ischemia, $\mathrm{pH}_{\mathrm{i}}$ rapidly falls, abolishing the transsarcolemmal $\mathrm{H}^{+}$ gradient. Upon reperfusion, $\mathrm{pH}_{\mathrm{i}}$ returns to control values within $4 \mathrm{~min}$ if reperfusion is with physiological buffer at $\mathrm{pH} 7.4$, and yet contractile amplitude remains depressed, although at a significantly decreased cell length. Thus the depression in contractility seen after $4 \mathrm{~min}$ of reperfusion cannot be ascribed to persistent intracellular acidosis.

The fourth, and important, observation is that if the brief overshoot in systolic $\left[\mathrm{Ca}^{2+}\right]_{\mathrm{i}}$ within the 1 st min of reperfusion as well as subsequent hypercontracture of most cells can be avoided by one of several maneuvers that alter the relationships among intracellular $\mathrm{H}^{+}$concentration $\left(\left[\mathrm{H}^{+}\right]_{\mathrm{i}}\right),\left[\mathrm{Ca}^{2+}\right]_{\mathrm{i}}$, and $\left[\mathrm{Na}^{+}\right]_{\mathrm{i}}$, then irreversible cellular injury, judged by absence of development of hypercontracture, may be obviated. There is considerable evidence that the $\mathrm{Ca}^{2+}$ influx that occurs with reperfusion does not occur appreciably via the $\mathrm{Ca}^{2+}$ channel, since $\mathrm{Ca}^{2+}$ channel blockers applied at reperfusion have minimal protective effect (29). However, if $\mathrm{Na}^{+}$influx is prevented during reperfusion by lowering extracellular $\mathrm{Na}^{+}$, by reperfusion in the presence of amiloride, or by reperfusion with a buffer whose $\left[\mathrm{H}^{+}\right]$is sufficient to maintain $\left[\mathrm{H}^{+}\right]_{i}$ equal to extracellular $\left[\mathrm{H}^{+}\right]$, there was a striking effect of abolishing the overshoot in $\left[\mathrm{Ca}^{2+}\right]_{\mathrm{i}}$ and preventing hypercontracture. Moreover, if $\mathrm{Na}^{+}$entry via the $\mathrm{Na}^{+}$channel is blocked during simulated ischemia, hypercontracture is also prevented.

\section{Mechanism of Transient Increase in $\left[\mathrm{Ca}^{2+}\right]_{i}$}

Why would $\left[\mathrm{Ca}^{2+}\right]_{\mathrm{i}}$ increase transiently upon reperfusion after simulated ischemia? Our data are consistent with the postulate that reperfusion-induced accumulation of intracellular $\mathrm{Na}^{+}$plays a pivotal role in reperfusion-induced cell injury by permitting transient $\mathrm{Ca}^{2+}$ overload via $\mathrm{Na}^{+}-\mathrm{Ca}^{2+}$ exchange. During ischemia in the intact heart (23) as well as in this single-cell model, the transsarcolemmal $\mathrm{H}^{+}$gradient is abolished and $\left[\mathrm{H}^{+}\right]_{\mathrm{i}}$ increases. With reperfusion, there is a step change in extracellular $\left[\mathrm{H}^{+}\right]$toward a lower concentration (higher $\mathrm{pH}$ ), resulting in cellular $\mathrm{H}^{+}$efflux and $\mathrm{Na}^{+}$influx via the $\mathrm{Na}^{+}-\mathrm{H}^{+}$exchanger. In many experimental models this has been demonstrated to be associated with an increase in $\left[\mathrm{Na}^{+}\right]_{\mathrm{i}}(21,28,33,43,44)$. An increase in $\left[\mathrm{Na}^{+}\right]_{\mathrm{i}}$ would therefore favor $\mathrm{Ca}^{2+}$ influx via $\mathrm{Na}^{+}-\mathrm{Ca}^{2+}$ exchange and very likely accounts for the transient overshoot in $\left[\mathrm{Ca}^{2+}\right]_{\mathrm{i}}$. We believe that a central role in the ischemiareperfusion injury in this model system is played by the $\mathrm{Na}^{+}-\mathrm{H}^{+}$exchanger and the $\mathrm{Na}^{+}-\mathrm{Ca}^{2+}$ exchanger at time of reperfusion. There is mounting evidence from a number of in vivo and in vitro studies that also favor this interpretation $(1,9,18,43)$. Recently, Anderson et al. (2), using an hypoxic reperfused rabbit heart model and nuclear magnetic resonance (NMR) to assess $\mathrm{pH}_{\mathrm{i}},\left[\mathrm{Na}^{+}\right]_{\mathrm{i}}$, and $\left[\mathrm{Ca}^{2+}\right]_{\mathrm{i}}$ demonstrated that $\mathrm{Na}^{+}$accumulation and hence $\mathrm{Ca}^{2+}$ accumulation was primarily due to $\mathrm{Na}^{+}-\mathrm{H}^{+}$ and $\mathrm{Na}^{+}-\mathrm{Ca}^{2+}$ exchange. $\mathrm{Na}^{+}$accumulation was shown to be due to increased entry rather than decreased extrusion. Their observations in an intact heart, using techniques distinct from those in the present study, are entirely consistent with and complementary to our observation in single cells subjected to simulated ischemia. Moreover, Pike et al. (36) found that in intact perfused ferret heart studied by NMR there is evidence for $\left[\mathrm{Na}^{+}\right]_{\mathrm{i}}$ remaining elevated briefly upon reperfusion, setting up gradients that could produce a brief overshoot in $\left[\mathrm{Ca}^{2+}\right]_{\mathrm{i}}$. Thus 
evidence from a number of experimental approaches is converging to support the pivotal role of $\mathrm{Na}^{+}$entry after hypoxia or ischemia. Blockade of $\mathrm{Na}^{+}$channel-dependent $\mathrm{Na}^{+}$entry with TTX ameliorates cells injury (Table 2). This observation also is consistent with the $\mathrm{Na}^{+}$-overload hypothesis. However, the present data do not permit one to entirely discount the alternate explanation that TTX is halting the action potential during ischemia and thereby directly limiting $\mathrm{Ca}^{2+}$ entry during depolarization. Because diastolic $\mathrm{Ca}^{2+}$ increases only slightly during ischemia (Fig. 2), we view the latter explanation of the TTX effect less likely.

It would be desirable to demonstrate directly in a single myocyte that $\left[\mathrm{Na}^{+}\right]_{\mathrm{i}}$ increases at time of reperfusion. To date, this has not been feasible because of shifts in spectral properties of $\mathrm{Na}^{+}$-sensitive dyes in the $\mathrm{pH} 6.50-7.00$ range. However, there can be little doubt that $\left[\mathrm{Na}^{+}\right]_{\mathrm{i}}$ does increase at the time of reperfusion in our model system. We have previously reported that ${ }^{24} \mathrm{Na}^{+}$content increases after hypoxia-reoxygenation in cultured myocytes $(29,31)$, and others have reported an increase after hypoxia-reoxygenation in intact heart (2) and after ischemia-reperfusion in the intact heart $(35,43)$. $\mathrm{Na}^{+}$influx via $\mathrm{Na}^{+}-\mathrm{H}^{+}$exchange is the most likely mechanism for a probable increase in intracellular $\mathrm{Na}^{+}$and subsequent $\mathrm{Ca}^{2+}$ overload by $\mathrm{Na}^{+}-\mathrm{Ca}^{2+}$ exchange. Although the amiloride data and low $\mathrm{pH}$ perfusion data support this postulate, we cannot exclude direct inhibition of $\mathrm{Na}^{+}$$\mathrm{Ca}^{2+}$ exchange by low $\mathrm{pH}$ or amiloride.

\section{Mechanism of Hypercontracture}

Why would a brief increase in systolic $\left[\mathrm{Ca}^{2+}\right]_{\mathrm{i}}$ to about two times control values be associated with failure of diastolic relaxation and development of hypercontracture? We have observed nearly this degree of increase in $\left[\mathrm{Ca}^{2+}\right]_{\mathrm{i}}$ during inotropic stimulation of myocytes, with no dire sequelae. The present data do not permit a definitive resolution of this paradox but suggest some possible explanations. First, $\left[\mathrm{Ca}^{2+}\right]_{i}$ estimated with the techniques used here report $\left[\mathrm{Ca}^{2+}\right]_{\mathrm{i}}$ very rapidly (9-ms sampling) but do not account for any buffering of $\mathrm{Ca}^{2+}$ that may be entering the cell and thus would be unavailable for binding fura-2, nor do they account for possible spatial gradients within the cell. Therefore $\left[\mathrm{Ca}^{2+}\right]_{\mathrm{i}}$ measurements may be grossly underestimating the total magnitude of $\mathrm{Ca}^{2+}$ influx and may miss spatially localized very high $\left[\mathrm{Ca}^{2+}\right]$.

It remains uncertain how reperfusion-associated $\mathrm{Ca}^{2+}$ influx early after 5 min of simulated ischemia commits the cell to development of contracture and probable cell death even after $\left[\mathrm{Ca}^{2+}\right]_{i}$ returns to a normal level and in normal $\left[\mathrm{H}^{+}\right]_{\mathrm{i}}$ and $[\mathrm{HEPs}]$. Hypercontracture in the presence of normal $\left[\mathrm{Ca}^{2+}\right]$ has been reported previously by Koyama et al. (22) for guinea pig myocytes, and for rat myocytes by Siegmund et al. (41) and Eisner et al. (12). Also, Harrison et al. (16) have reported hysteresis for the pCa-tension relationship in rat cardiac muscles. Development of hypercontracture, in our case defined as decrease in diastolic cell length to $<60 \%$ of control, has been used by a number of other investigators as an index of irreversible cell injury $(3,11,17,41)$. Siegmund et al. (41) have demonstrated at the ultrastructural level that, in rat myocytes, hypercontracture after anoxia-reperfusion is associated with extensive sarcolemmal bleb formation and is rarely reversible. Regardless of the degree of abnormality of $[\mathrm{HEPs}]$ or $\left[\mathrm{Ca}^{2+}\right]_{\mathrm{i}}$ before development of contracture, after contracture in most cells the sarcolemma promptly loses integrity as judged by accumulation of trypan blue.

The current data do permit at least a provisional conclusion that the $\mathrm{Ca}^{2+}$ influx associated with reperfusion does not appear to produce cell death by causing mitochondrial failure in this model. During reperfusion HEPs are resynthesized.

What is the mechanism of cellular injury in this model of ischemia and reperfusion if it is not solely due to HEP depletion? We speculate that the transient overshoot in systolic $\left[\mathrm{Ca}^{2+}\right]_{\mathrm{i}}$ and/or masked $\mathrm{Ca}^{2+}$ accumulation by organelles and binding sites may activate phospholipases or proteases that could increase membrane permeability and produce inevitable irreversible injury, even though $\left[\mathrm{Ca}^{2+}\right]_{\mathrm{i}}$ can be at least transiently restored to its normal range. Alternatively, arrest and then resumption of oxidative metabolism might favor generation of oxygen-derived free radicals, which have been demonstrated to produce reperfusion injury in vivo (30). We have previously reported that in an hypoxia-reoxygenation cultured myocyte model system, free radical scavengers can limit "reperfusion" injury, suggesting that a system such as this that is devoid of leukocytes and endothelial elements can still generate oxygen-derived free radicals (29).

\section{Isolated Single Myocyte Model}

The simplified model of ischemic injury used for these experiments deserves comment. We used the isolated adult rat ventricular myocyte model, in which contractile function in single cells could be monitored simultaneously with acquisition of fluorescence emission spectra that varied in proportion to change in intracellular $\mathrm{Ca}^{2+}$ or $\mathrm{H}^{+}$ activities and a buffer system to simulate ischemia and reperfusion. Of note, the absolute values for $\left[\mathrm{Ca}^{2+}\right]_{i}$ (systolic and diastolic) under control conditions and the percentage change under simulated ischemic conditions are similar to those of intact heart by Kihara et al. (20) using a different intracellular indicator of $\left[\mathrm{Ca}^{2+}\right]_{\mathrm{i}}$, aequorin, in the intact ferret heart and are comparable to results of Lee et al. (25) using indo-1 in the intact rabbit heart. Single-cell models for the study of mechanisms of ischemic injury are well established and have been widely used for many years $(10,12,19,22,24,26,29,37,41)$. Most previous studies have taken a more limited approach than in the current investigation, examining cells subjected to hypoxia (42) or to metabolic inhibition, most commonly with cyanide and 2-deoxyglucose, as were used in the current investigation (11). 2-Deoxyglucose, an irreversible inhibitor of glycolysis, has little effect by itself on most single-cell model systems as long as aerobic metabolism could be maintained. Cyanide specifically and reversibly inhibits mitochondrial electron transport in a well-characterized manner similar to removal of molecular oxygen (11). The present study extends the metabolic inhibition model of ischemia to include concentrations of important molecules found in the interstitium of reversibly ischemic heart and is similar to the model of Koyama 
et al. (22) and Ferrier et al. (14). Thus [lactate] and $\left[\mathrm{K}^{+}\right]$ were chosen to be similar to values reported by Cascio et al. (8) for the intact reversibly ischemic heart. When individual components of the ischemia buffer were examined, we found that $12 \mathrm{mM} \mathrm{K}^{+}$by itself only depressed contractile amplitude and did not produce contracture. Lactate alone had a similar effect. We used an extracellular $\mathrm{pH}(6.5-6.8)$ reported to be present in reversible ischemia in situ $(23,43)$ and a $\mathrm{pH}$ that will affect cardiac activation (4). In myocytes, we previously reported that acidosis alone depressed amplitude of contraction but did not lead to hypercontracture. Moreover, acidosis alone did not abolish the $\left.\mathrm{H}^{+}\right]$gradient (28). Thus, although still an approximation of ischemia in situ, the model is more complete than previous single-cell approaches. The effects of simulated ischemia-reperfusion cannot be attributed to only one component of the buffer.

Limitations of the system include the fact that the cells are only lightly loaded during contraction, and thus the time course and magnitude of HEP content changes are blunted compared with those observed in an intact heart. Moreover, HEP concentrations cannot be determined on-line as in NMR studies, so that one can only estimate changes in these concentrations. However, these measurements are not the central point of the investigation. Offsetting somewhat the limitations of the model are its considerable strength, including the ability to carefully define and modify extracellular ion concentrations and measure $\left[\mathrm{H}^{+}\right]_{\mathrm{i}}$ and $\left[\mathrm{Ca}^{2+}\right]_{\mathrm{i}}$ transients with high temporal resolution, which is not possible by NMR. Moreover, fura-2 offers better sensitivity and reliable estimates of $\left[\mathrm{Ca}^{2+}\right]_{\mathrm{i}}$ at low diastolic range $\mathrm{Ca}^{2+}$ concentrations than afforded by an alternative $\mathrm{Ca}^{2+}$ indicator, aquerion.

In summary, we have demonstrated that $\left[\mathrm{Ca}^{2+}\right]_{\mathrm{i}}$ estimated by the fura-2 fluorescence ratio in isolated adult rat myocytes increases transiently when cells were exposed to simulated ischemia conditions and then reperfused. The increase in $\left[\mathrm{Ca}^{2+}\right]_{i}$ was associated with development of hypercontracture, which continued and were irreversible after $\left[\mathrm{Ca}^{2+}\right]_{\mathrm{i}}$ returned to normal level. $\mathrm{Na}^{+}$ and then $\mathrm{Ca}^{2+}$ entry via $\mathrm{Na}^{+}-\mathrm{H}^{+}$exchangers and $\mathrm{Na}^{+}$$\mathrm{Ca}^{2+}$ exchangers probably contributes to the increase in $\left[\mathrm{Ca}^{2+}\right]_{i}$. This $\mathrm{Na}^{+}$-dependent transient increase in $\left[\mathrm{Ca}^{2+}\right]_{i}$ appears to be the pivotal event in cell injury in this model.

The excellent technical assistance of Robin Brewer, Darlene Toupin, and Stephanie Murphy and excellent secretarial assistance by Michelle Somers are appreciated.

This work was supported in part by National Heart, Lung, and Blood Institute Grants R01-HL-35781 and R01-HL-36141.

Address for reprint requests: J. D. Marsh, Wayne State University, 421 E. Canfield Ave., Rm. 1107, Detroit MI 48201.

Received 29 June 1992; accepted in final form 12 January 1993.

\section{REFERENCES}

1. Allen, D. G., and C. H. Orchard. Myocardial contractile function during ischemia and hypoxia. Circ. Res. 60: 153-158, 1987.

2. Anderson, S. E., E. Murphy, C. Steenbergen, R. E. London, and P. M. Cala. Na-H exchange in myocardium: effects of hypoxia and acidification on $\mathrm{Na}$ and Ca. Am. J. Physiol. 259 (Cell Physiol. 28): C940-C948, 1990.

3. Barry, W. H., G. A. Peeters, C. A. F. Rasmussen, Jr., and M. J. Cunningham. Role of changes in $\left[\mathrm{Ca}^{2+}\right]_{\mathrm{i}}$ in energy depri- vation contracture. Circ. Res. 61: 726-734, 1987.

4. Blanchard, E. M., and R. J. Solaro. Inhibition of the activation and troponin calcium binding of dog cardiac myofibrils by acidic pH. Circ. Res. 55: 382-391, 1984.

5. Borzak, S., R. A. Kelly, B. A. Kraemer, Y. Matoba, J. D. Marsh, and M. Reers. In situ calibration of fura-2 and BCECF fluorescence in adult rat ventricular myocytes. Am. J. Physiol. 259 (Heart Circ. Physiol. 28): H973-H981, 1990.

6. Borzak, S., S. Murphy, and J. D. Marsh. Mechanism of rate staircase in rat ventricular cells. Am. J. Physiol. 260 (Heart Circ. Physiol. 29): H884-H892, 1991.

7. Braunwald, E., and R. A. Kloner. Myocardial reperfusion: a double-edge sword? J. Clin. Invest. 76: 1713-1719, 1985.

8. Cascio, W. E., G. X. Yan, and A. B. Kleber. Passive electrical properties, mechanical activity, and extracellular potassium in arterially perfused and ischemic rabbit ventricular muscle. Circ. Res. 66: 1461-1473, 1990.

9. Currin, R. T., G. J. Gores, R. G. Thurman, and J. J. Lemasters. Protection by acidotic $\mathrm{pH}$ against anoxic cell killing in perfused rat liver: evidence for a $\mathrm{pH}$ paradox. FASEB J. 5: 207-210, 1991.

10. Dennis, S. C., W. A. Coetzee, E. J. Cragoe, Jr., and L. H. Opie. Effects of proton buffering and of amiloride derivatives on reperfusion arrhythmias in isolated rat hearts: possible evidence for an arrhythmogenic role of $\mathrm{Na}^{+}-\mathrm{H}^{+}$exchange. Circ. Res. 66: 1156-1159, 1990.

11. Doorey, A. J., and W. H. Barry. The effects of inhibition of oxidative phosphorylation and glycolysis on contractility and high-energy phosphate content in cultured chick heart cells. Circ. Res. 53: 192-201, 1983.

12. Eisner, D. A., C. G. Nichols, S. C. O'Neill, G. L. Smith, and M. Valdeolmillos. The effects of metabolic inhibition on intracellular calcium and $\mathrm{pH}$ in isolated rat ventricular cells. J. Physiol. Lond. 411: 393-418, 1989.

13. Esumi, K., M. Nishida, D. Shaw, T. W. Smith, and J. D. Marsh. NADH measurements in adult rat myocytes during simulated ischemia. Am. J. Physiol. 260 (Heart Circ. Physiol. 29): H1743-H1752, 1991.

14. Ferrier, G. R., M. P. Moffat, and A. Lukas. Possible mechanisms of ventricular arrhythmias elicited by ischemia followed by reperfusion. Circ. Res. 56: 184-194, 1985.

15. Grynkiewicz, G., M. Poenie, and R. Y. Tsien. A new generation of $\mathrm{Ca}^{2+}$ indicators with greatly improved fluorescence properties. J. Biol. Chem. 260: 3440-3450, 1985.

16. Harrison, S. M., C. Lamont, and D. J. Miller. Hysteresis and the length dependence of calcium sensitivity in chemically skinned rat cardiac muscle. J. Physiol. Lond. 401: 115-143, 1988.

17. Haworth, R. A., D. R. Hunter, and H. A. Berkoff. Contracture in isolated adult heart cells. Circ. Res. 49: 1119-1128, 1981.

18. Hohl, C., A. Ansel, R. Altschuld, and G. P. Brierley. Contracture of isolated rat heart cells on anaerobic to aerobic transition. Am. J. Physiol. 242 (Heart Circ. Physiol. 11): H1022-H1030, 1982.

19. Ishida, H., O. Kohmoto, J. H. B. Bridge, and W. H. Barry. Alteration in cation homeostasis in cultured chick ventricular cells during and after recovery from adenosine trisphosphate depletion. J. Clin. Invest. 81: 1173-1181, 1988.

20. Kihara, Y., W. Grossman, and J. P. Morgan. Direct measurement of changes in intracellular calcium transients during hypoxia, ischemia, and reperfusion of the intact mammalian heart. Circ. Res. 65: 1029-1044, 1989.

21. Kim, D., E. J. Cragoe, Jr., and T. W. Smith. Relation among sodium pump inhibition, $\mathrm{Na}-\mathrm{Ca}$ and $\mathrm{Na}-\mathrm{H}$ exchange activities, and $\mathrm{Ca}-\mathrm{H}$ interaction in cultured chick heart cells. Circ. Res. 60: 185-193, 1987

22. Koyama, T., K. Temma, and T. Akera. Reperfusion-induced contracture develops with a decreasing $\left[\mathrm{Ca}^{2+}\right]_{\mathrm{i}}$ in isolated cardiac myocytes. Am. J. Physiol. 261 (Heart Circ. Physiol. 30): H1115H1122, 1991.

23. Kusuoka, H., Y. Koretsune, V. P. Chacko, M. L. Weisfeldt, and E. Marban. Excitation-contraction coupling in postischemic myocardium; does failure of activator $\mathrm{Ca}^{2+}$ transients underlie stunning? Circ. Res. 66: 1268-1276, 1990. 
24. Lederer, W. J., C. G. Nichols, and G. L. Smith. The mechanism of early contractile failure of isolated rat ventricular myocytes subjected to complete metabolic inhibition. J. Physiol. Lond. 413: 329-349, 1989.

25. Lee, H., R. Mohabir, N. Smith, M. R. Franz, and W. T. Clusin. Effect of ischemia on calcium-dependent fluorescence transients in rabbit hearts containing indo 1: correlation with monophasic action potentials and contraction. Circulation 78: 1047-1059, 1988.

26. Li, Q., R. A. Altshuld, and B. T. Stokes. Myocyte deenergization and intracellular free calcium dynamics. Am. J. Physiol. 255 (Cell Physiol. 24): C162-C168, 1988.

27. Lowry, O. H., N. J. Rosebrough, A. L. Farr, and R. J. Randall. Protein measurement with the Folin phenol reagent. $J$. Biol. Chem. 193: 265-275, 1951.

28. Marsh, J. D., T. I. Margolis, and D. Kim. Mechanism of diminished contractile response to ischemia during acidosis. Am. J. Physiol. 254 (Heart Circ. Physiol. 23): H20-H27, 1988.

29. Murphy, J., T. W. Smith, and J. D. Marsh. Mechanisms of reoxygenation-induced calcium overload in chick embryo heart cells. Am. J. Physiol. 254 (Heart Circ. Physiol. 23): H1133-H1141, 1988.

30. Myers, M. L., R. Bolli, R. F. Lekick, C. J. Hartley, and R. Roberts. Enhancement of recovery of myocardial function by oxygen free-radical scavengers after reversible regional ischemia. Circulation 72: 915-921, 1985.

31. Navas, J. P., W. Anderson, and J. D. Marsh. Hypoxia increases calcium overload of hypoxic myocytes. Am. J. Physiol. 259 (Heart Circ. Physiol. 28): H333-H339, 1990.

32. Nayler, W. G., and J. S. Elz. Reperfusion injury: laboratory artifact or clinical dilemma? Circulation 74: 215-221, 1986.

33. Nayler, W. G., R. Ferrari, P. A. Poole-Wilson, and C. E. Yepez. A protective effect of a mild acidosis on hypoxic heart muscle. J. Mol. Cell Cardiol. 11: 1053-1071, 1979.

34. Opie, L. H. Reperfusion injury and its pharmacologic modification. Circulation 80: 1049-1062, 1989.

35. Panagiotopoulos, S., M. J. Daly, and W. G. Nayler. Effect of acidosis and alkalosis on postischemic $\mathrm{Ca}$ gain in isolated rat heart. Am. J. Physiol. 258 (Heart Circ. Physiol. 27): H821-H828, 1990.

36. Pike, M. M., M. Kitakaze, and E. Marban. ${ }^{23} \mathrm{Na}-\mathrm{NMR}$ measurements of intracellular sodium in intact perfused ferret hearts during ischemia and reperfusion. Am. J. Physiol. 259 (Heart Circ. Physiol. 28): H1767-H1773, 1990.

37. Piper, H. M. Energy deficiency, calcium overload or oxidative stress: possible causes of irreversible ischemic myocardial injury. Klin. Wochenschr. 67: 465-476, 1989.

38. Poole-Wilson, P. A., D. P. Harding, P. D. V. Bourdillon, and M. A. Tones. Calcium out of control. J. Mol. Cell Cardiol. 16: 175-187, 1984.

39. Reers, M., R. A. Kelly, and T. W. Smith. Calcium and proton activities in rat cardiac mitochondria. Effect of matrix environment on behavior of fluorescent probes. Biochem. J. 257: 131-142, 1989.

40. Shepherd, N., M. Vornanen, and G. Isenberg. Force measurements from voltage-clamped guinea pig ventricular myocytes. Am. J. Physiol. 258 (Heart Circ. Physiol.): H4452-H4459, 1990.

41. Siegmund, B., T. Schwartz, and H. M. Piper. Temporary contractile blockade prevents hypercontracture in anoxic-reoxygenated myocytes. Am. J. Physiol. 260 (Heart Circ. Physiol. 29): H426-H435, 1991.

42. Stern, M. D., J. S. Silverman, S. R. Houser, R. A. Josephson, M. C. Capagrossi, C. G. Nichols, W. J. Lederer, and E. G. Lakatta. Anoxia contractile failure in rat heart myocytes is caused by failure of intracellular calcium release due to alterations in the action potential. Proc. Natl. Acad. Sci. USA 85: 6954-6958, 1988.

43. Tani, M., and J. R. Neely. Role of intracellular $\mathrm{Na}^{+}$in $\mathrm{Ca}^{2+}$ overload and depressed recovery of ventricular function of reperfused ischemic rat heart: possible involvement of $\mathrm{H}^{+}-\mathrm{Na}^{+}$and $\mathrm{Na}^{+}-\mathrm{Ca}^{2+}$ exchange. Circ. Res. 65: 1045-1056, 1989.

44. Vanheel, B., A. Dehamptenne, and I. Leasen. Acidification and intracellular sodium ion activity during simulated myocardial ischemia. Am. J. Physiol. 259 (Cell Physiol. 28): C169-C179, 1990. 